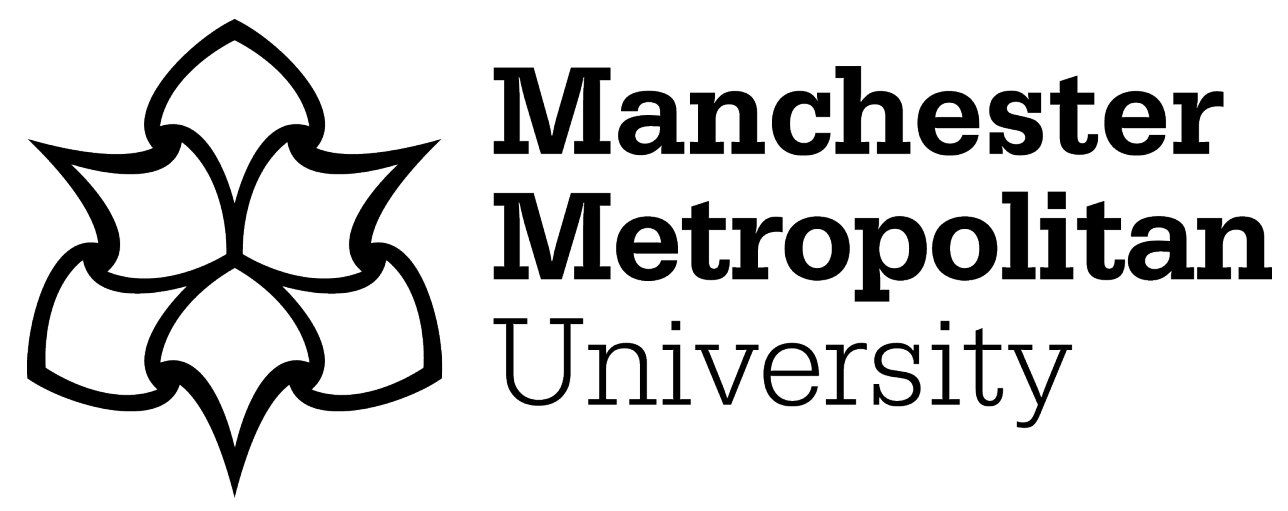

Beel, David ORCID logoORCID: https://orcid.org/0000-0002-1146-229X and Jones, Martin (2021) City region limits: Questioning city-centric growth narratives in medium-sized cities. Local Economy: The Journal of the Local Economy Policy Unit, 36 (1). pp. 3-21. ISSN 0269-0942

Downloaded from: https://e-space.mmu.ac.uk/627974/

Version: Published Version

Publisher: SAGE Publications

DOI: https://doi.org/10.1177/02690942211015778

Usage rights: Creative Commons: Attribution 4.0

Please cite the published version 


\title{
City region limits: Questioning city-centric growth narratives in medium-sized cities
}

Local Economy $0(0) 1-19$

(C) The Author(s) 2021

(c) (i)

Article reuse guidelines: sagepub.com/journals-permissions DOI: I0.1 I77/026909422। I0I5778

journals.sagepub.com/home/lec

David Beel (D)

Manchester Metropolitan University, UK

\section{Martin Jones}

Staffordshire University, UK

\begin{abstract}
In this paper, we consider the implications of applying the city region concept to a medium-sized city and whether such an application of a spatial and governmental policy is appropriate when the central city in question is also not necessarily economically dominant or connected to its wider city-region. This gives a deeper understanding to the process of subnational restructuring of the UK state via the production of city regions which has now been in progress since the 2010 Coalition Government. The primary focus governmentally and in academic literature has been on larger (English) city regions, but here we highlight how this has been applied in distinctive ways in devolved nations of the UK. To this end, we focus upon the case of the Swansea Bay City Region, based in South West Wales, looking through the lens of Welsh devolution and through the concept of the city-region as a scalar narrative for the delivery of economic development.
\end{abstract}

\section{Keywords}

city region, devolution, economic development, governance, Wales

This City Deal will provide the region and its partners with the new ways of working and resources to unlock significant economic growth across the Swansea Bay City Region. It is a Deal where both Welsh and UK Governments have committed to jointly invest, subject to the submission and approval of full business cases in relation to the eleven identified projects and the agreement of governance arrangements for the deal, up to $£ 241$ million on specific interventions which seek to support and further build on the region's strengths which include health, energy and

\footnotetext{
Corresponding author:

David Beel, Economics, Policy \& International Business (EPIB), School of Business and Law, Manchester Metropolitan University, Manchester MI5 6BH, UK. Email: d.beel@mmu.ac.uk
} 
manufacturing sectors and are underpinned by a world-class digital infrastructure, successful universities and innovative health boards. (HM Government, 2017: 3)

\section{Introduction}

In this paper, we consider the implications of applying the city-region concept to a medium-sized city and whether such an application of a spatial and governmental policy is appropriate when the central city in question is also not necessarily economically dominant or connected to its wider city-region. This raises the wider question that within the process of sub-nation state restructuring, how can the city-region construct deal with its application in what are often 'relational' and 'stretched' (MacLeod and Jones, 2007) polycentric city-regional contexts. We focus on the case of the Swansea Bay City Region (SBCR), based in South West Wales, observed through the lens of Welsh devolution and through the concept of the city-region as a scalar narrative for the delivery of economic development.

This paper suggests that as a concept for delivering economic growth in Wales, the 'fit' of the city-region concept to Swansea Bay pushes the very essence and dynamics of the economic model in question to its spatial limits, hence the title. This is questioned via comprehending how and why the scale and differences across the SBCR stretch the spatial construct of city-region building. Swansea as a smaller, geographically peripheral UK metropolitan centre lacks economic dominance over a cityregion, which is polycentric and porous in its social and spatial nature. This means it struggles to embed the dynamics of the cityregion neoliberal growth machine model into a coherent centric local growth framework. This, in turn, suggests that with regard to sub-national state spatial restructuring in Wales, a different model of economic development may well be much better to suited to this region in question. Our critique, then, is not just applicable to Swansea Bay, but also to other medium and smaller sized city-regions attempting to deliver a city-region agenda. The transference of the city-region as a geopolitical policy footprint for economic growth (Jonas and Moisio, 2016), therefore, needs to be more carefully thought through in its implementation. Its usage, whereby, a city-first or urban centric model is deployed without a dominant agglomerative centre, becomes mired in the difficulties of the more complex and diverse economic geographies.

The growing pre-eminence of the 'cityregion' as the de facto spatial political unit of governance for economic development (Clarke and Cochrane, 2013) has been a global trend in urban and regional development planning (Harrison, 2014). This trend has seen attempts to implement city-region governance arrangements around a metropolitan core in order to foster economic growth via agglomeration. With the increasing popularity of this approach as a policy for economic growth, the spreading of the city-region growth machine can be seen as a policy transfer (Peck and Theodore, 2015). With any transference of policy, it is transformed by its mobility and delivery in a new place. In this paper, we consider the implications of moving and applying the city-region concept to a medium-sized city and whether such an application of a spatial and governmental policy is appropriate when the central city in question is not necessarily economically dominant or connected to its wider region. This raises the wider question that within the process of sub-nation state restructuring, how can the city-region construct deal with its application in what are often polycentric city-regions. 
The subnational restructuring of the UK state via the production of city-regions has now been in progress since the 2010 Coalition Government. This has seen a primary focus on English city regions, but this has also been applied in distinctive ways in devolved nations of the UK with the development of city regions in both Wales and Scotland. In this paper, we focus upon the case of the SBCR, based in South West Wales, looking through the lens of Welsh devolution and through the concept of the city-region as a scalar narrative for the delivery of economic development. In the UK, this has been led by the UK Government, as they have sought to reshape the ways in which economic development takes place and although this shift in governmental delivery began under New Labour. It was much vaunted by the UK Coalition Government (Deas, 2013), subsequently by the continuing Conservative administration (Conservative Party, 2015). This policy trajectory has found a presence in Wales too, with the two Welsh city-regions (Cardiff and Swansea) both gaining city-deals via the UK and Welsh governments.

The process of city-deal making though is one that seeks to enable elite actors to deliver economic growth within the respective city-region (Waite et al. 2013; O'Brien and Pike, 2019). This raises several interesting empirical and theoretical concerns with

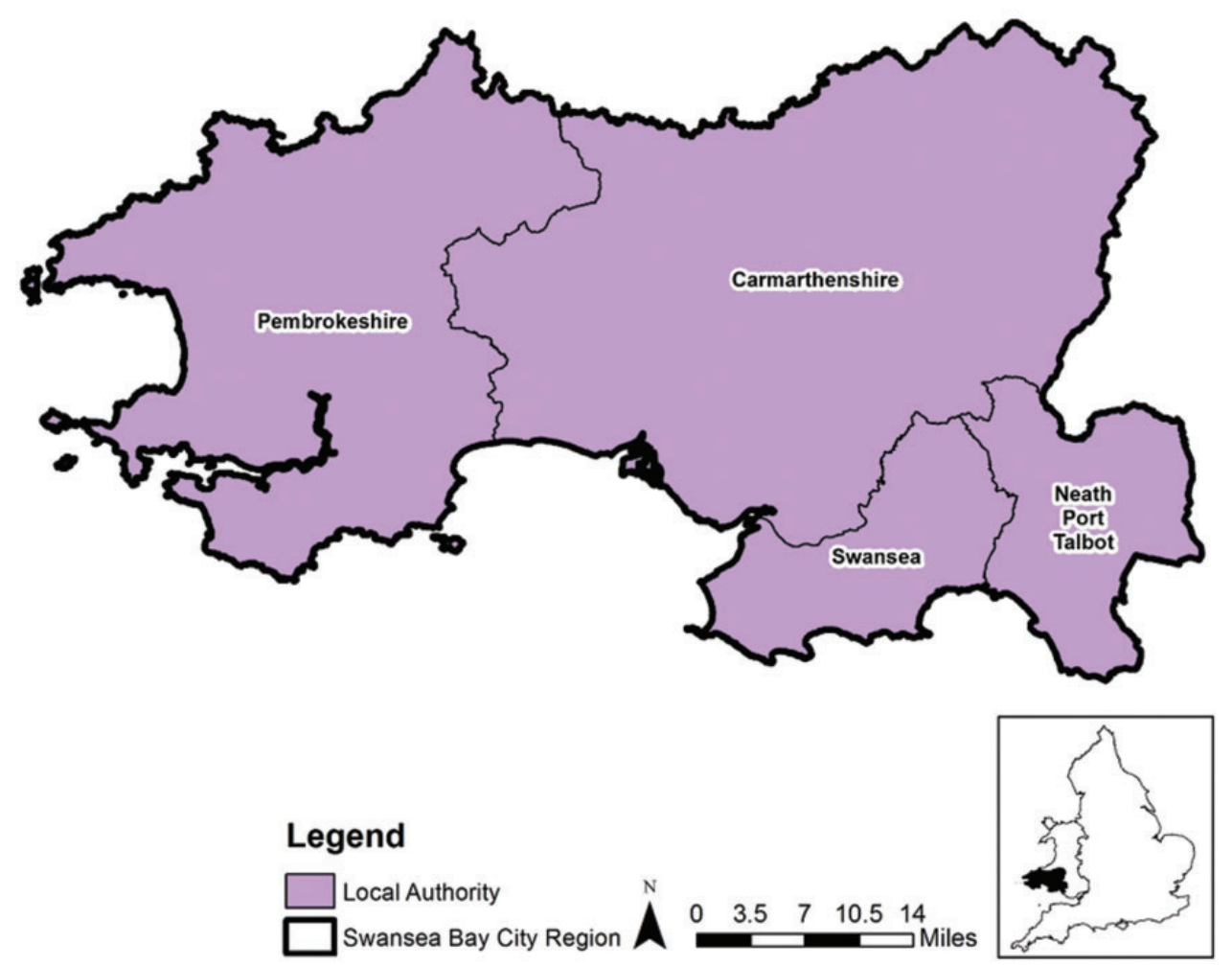

Figure I. Swansea Bay City Region. 
regard to the implementation of subnational economic policy in the wake of devolution and austerity (Waite, 2015; Etherington and Jones, 2016; 2018). In this paper, we suggest that the use of the city-region for driving growth in the UK and with regard to Swansea Bay stretches the concept beyond its useful application. This is because, as a concept for delivering economic growth in Wales (Beel et al., 2018; Blackaby et al., 2018), the fit of the city region concept to Swansea Bay pushes the very dynamics of the economic model in question to its limits. This is questioned via comprehending how the scale and differences across the SBCR (see Figure 1) stretch the spatial construct to its limits, Swansea as a smaller, geographically peripheral UK metropolitan centre lacks economic dominance over a city-region that is polycentric in nature. This means it struggles to embed the dynamics of the cityregion neoliberal growth machine model into a local growth framework. This suggests, with regard to sub-nation state restructuring in Wales, a different model may well be much better to suited to the region. This critique is not just applicable to Swansea Bay but to other medium and smaller sized city regions attempting to deliver a city region agenda. The transference of the city region as a geo-political policy footprint for economic growth (Jonas and Moisio, 2016) therefore needs to be more carefully thought through in its implementation. Its usage, whereby, a city-first or urban centric model (O'Brien and Pike, 2015) is deployed, becomes mired in the difficulties of the more complex and diverse economic geographies city regions have when there is not a more dominant urban centre.

To address our wider conceptual arguments with regard to city-regions, as well as the implementation of the $\mathrm{SBCB}$, the paper is organised in three sections.
The paper first develops further some of the conceptual arguments with regard to city-region building, to situate Swansea within its nuanced contexts. The second details the SBCR within the City Deal Approach being deployed by the UK and Welsh Governments. The third section looks at the emerging caveats and critiques of this approach to local and regional economic development in this part of South Wales.

\section{The city-regional world revisited}

With the city-region becoming the dominant discourse in urban development policy and the appropriate scale on which economic actors can position themselves within the global economy as 'scalarly' sufficient to react to changes, we have suggested throughout this paper that agglomeration tendencies privilege economic growth on centralised urban areas. Here, the consensus relates to the idea that if you centralise as much of your economic activity as possible, greater economic returns follow from spatial proximity and in turn, cumulative causation can operate (see Nathan and Overman, 2013; Overman and Venables, 2007). The city-region model has thus shaped economic growth policy as a metropolitan scale concern that lends itself to the critique of 'metrophilia' - the 'sweeping tendency' to present cities as panaceas for a myriad of economic and social challenges, in the process ignoring the needs of 'marginalised strata' within the city and of 'non-metropolitan places' beyond the city (Waite and Morgan, 2018: 384).

The critical approach to metrophilia is useful in the context of this paper as it highlights the way in which despite the vaunted 'bespoke' nature of the city-region building process, it is underpinned by a city-first agenda, which places far more emphasis on the importance of the urban. This in the context of some city-regions may posit 
some forms of success, but as this policy framework is applied to ever more varied cities and regions, the underpinning approach becomes much less applicable and plausible. The economic rationale of defining city-regions by their 'functional' or 'natural' economic area draws attention to the need to also examine the spaces of economic and social flows vis-a-vis travel to work areas (TTWA) around the city-region. This can sometimes cross pre-existing and historic administrative and cultural boundaries, as well as reflect the different spatial structures of settlements and the geographies of urban and rural economic growth. In the case of Swansea Bay, as the paper will develop, as a medium-sized city in an enlarged geographical city-region, it lacks the agglomerative pull economically to make the city-region function as for example Storper (2013) would suggest. This means that due to weak economic ties alongside a polycentric makeup of other settlements such as Llanelli, Carmarthen, Neath, and Port Talbot, the city-region model for economic growth is both ill-conceived and ill-fitted in its application upon Swansea Bay. This does not, however, stop the process of city-region building taking place, in what Haughton et al. (2016: 356) would suggest is informed by 'decontextualized economic theory that uses abstract economic laws to develop problematic policy prescriptions focused on the assumed potential of large cities to generate growth'. Haughton et al. are taking aim at agglomeration as a model for growth directly as well as the cityregion concept more broadly and it is within this critique that we see parallels to the SBCR's attempt to implement and harness such policy concepts. This follows with Waite and Morgan (2018) above, in that the city-region concept is mistakenly being applied as a 'panacea' for a series of economic problems. This means, it is ill equipped to actually address them, namely to fit the pre-existing geography or to provide any real 'inclusive growth' (see Lee, 2019); in many respects, through agglomeration, it has the potential to exacerbate uneven development.

\section{Swansea Bay City Region and City Deal}

The city-region as a policy construct for economic development is built on a variety of factors that attempt to institutionalise an agglomeration economy over time and across space. The opportunity to territorialise this city-region came through city deals, which create a bounded 'SBCR, but in doing so, also create the conditions for a series of contradictions and tensions within this mode of state intervention. These tensions reflect the relatively small economic foot print of Swansea, as the metropolitan centre in a wider a region (see Figure 1), but also refuel the difficult and competitive geographies of the Welsh state, whereby the two primary cities of Wales (Swansea and Cardiff) are relatively close in geographical proximity, contain collectively the largest proportion of the Welsh population, and have historically been deeply competitive with each other (see Gooberman, 2017). This makes delivering a sub-nation state structure for Wales and particularly South Wales difficult. Therefore, piecing together that perceived sense of scale for Swansea Bay is difficult, as it is required to stretch into a rural hinterland and it is constrained to the east by the Cardiff Capital Region (CCR) and its own economic footprint.

The SBCR consists of the four local authority areas that make up what could loosely be called 'South West Wales'. The city-region therefore includes Pembrokeshire, Carmarthenshire, Neath and Port Talbot and Swansea itself, with the latter two being more distinctively rural. This urban/rural (see 


\section{Wales Statistics classification of settlement type and context Lower level super output areas. August $\mathbf{2 0 0 5}$}

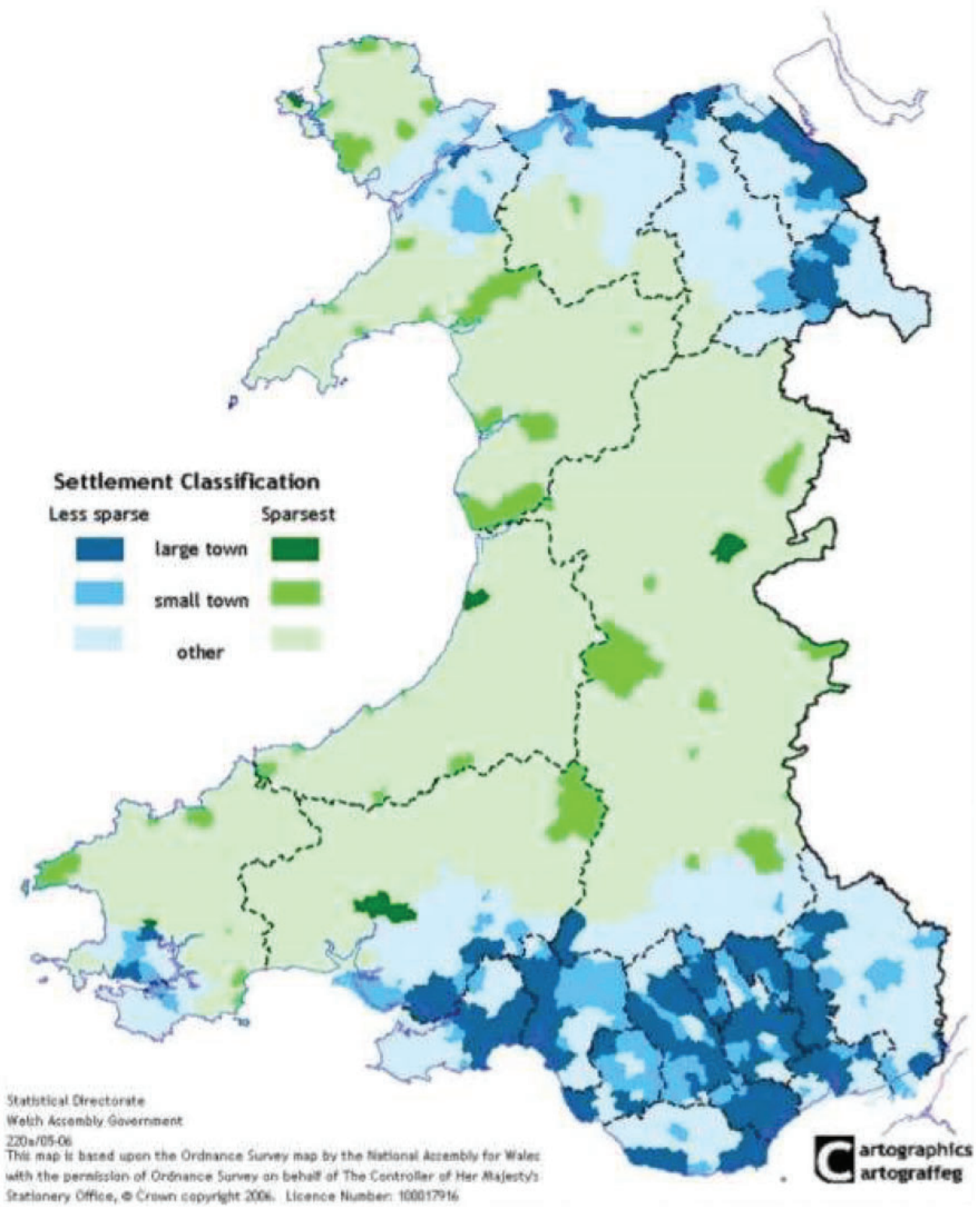

Figure 2. Urban/rural Wales (Welsh Government, 2008). 


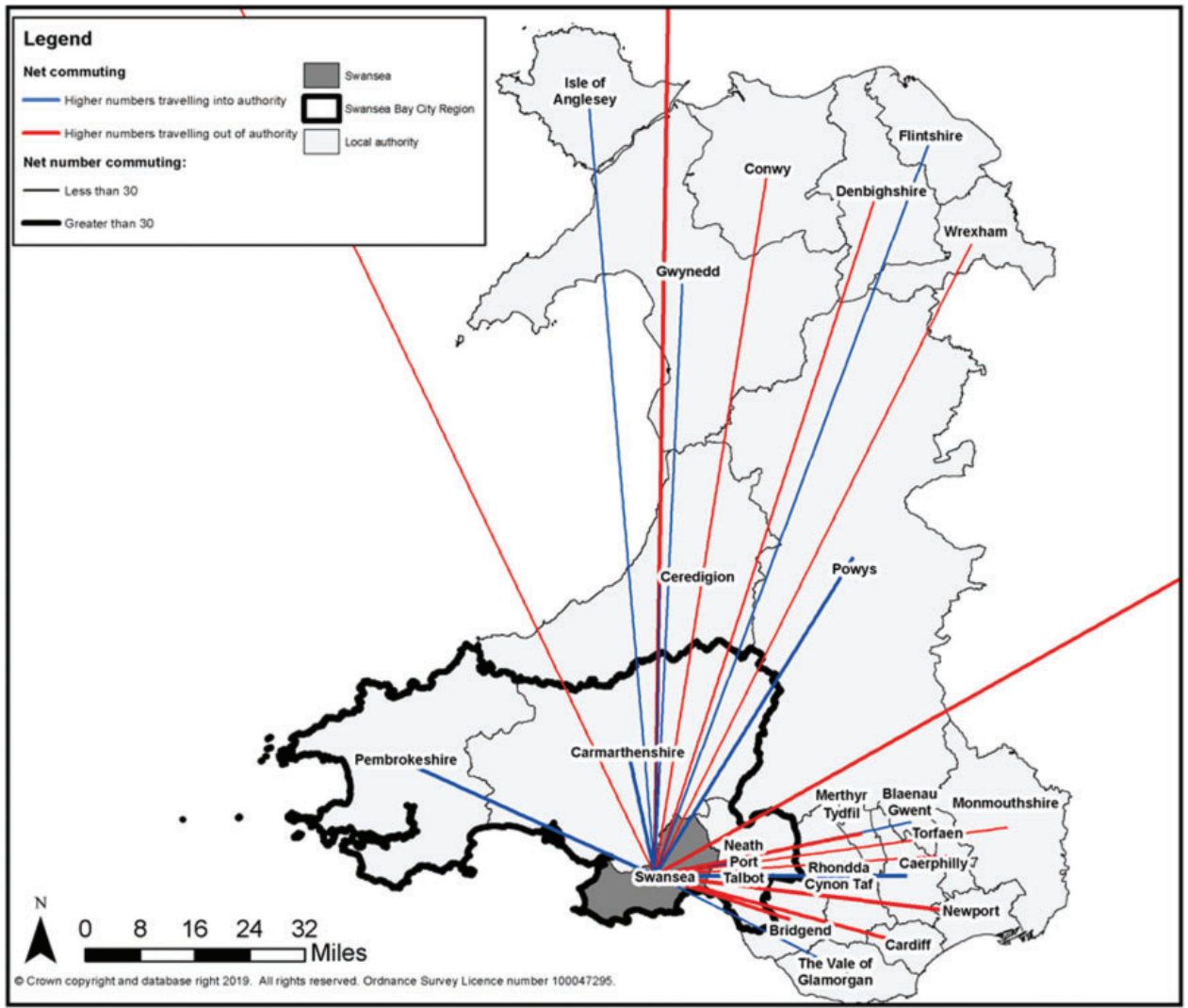

Figure 3. Swansea travel to work flows.

Figure 2) split between the local authorities is considerable and the economic footprint of Swansea itself, as the metropolitan centre across the region is relatively small.

Using TTWA data as a proxy for the economic connectedness of the city-region, Swansea has relatively weak connections to its rural hinterlands. Figures 3 to 5 highlight this picture, suggesting that there is little in the way of flow between Swansea and the rural parts of Carmarthenshire and Pembrokeshire itself. There is little travel between these local authorities to Swansea for work, alongside there being relatively weak infrastructure connections (whether road or rail) to even facilitate this, which over time has significant impact on patterns of economic development and settlement growth. This is reflected in Figure 3, which highlights the flows of people travelling to work across the region, here Swansea does see higher number of people travelling in from the surrounding local authorities (LAs) but it also sees a considerably higher flow of people travelling east for work out of Swansea. This is reflected in the overall figures for Swansea, whereby there is only a net inflow of +8400 people for work (Swansea Council, 2020). When this is placed alongside Figure 4, showing average commuting times into Swansea, it shows how rapidly commute time increases as distance from the urban centre increases, with large parts of the city-region being well over an hour in commuting time. Figure 5 then further represents this and the 


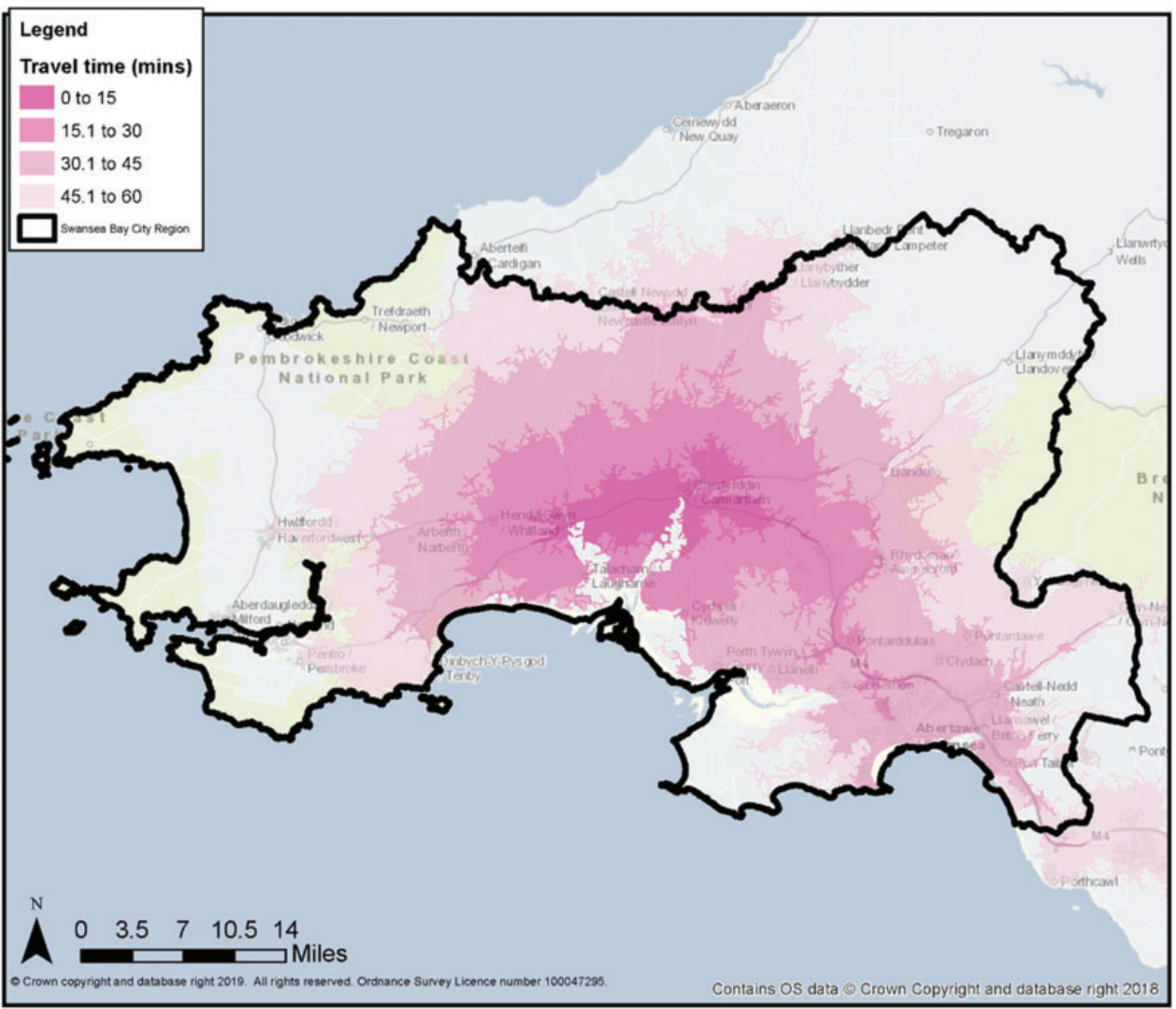

Figure 4. City-region travel times.

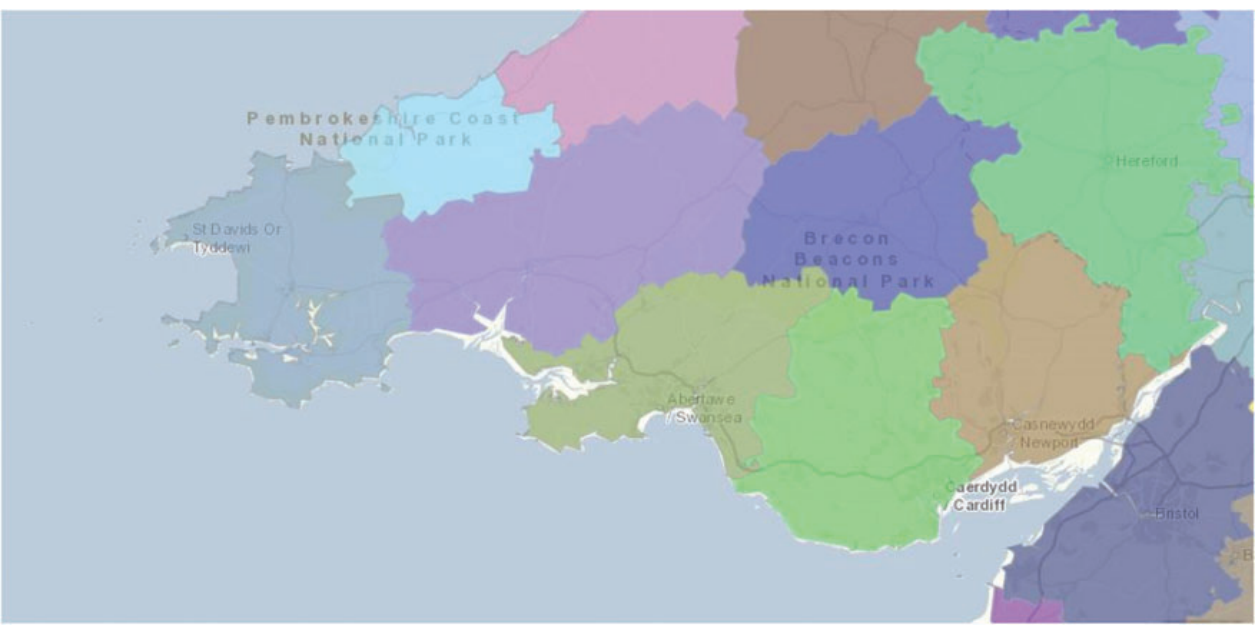

Figure 5. South Wales travel to work areas. 
Table I. Swansea Bay City Region descriptive statistics (Welsh Government, 2019).

\begin{tabular}{lllllll}
\hline & & & & & & Enterprises \\
Local authority & $\begin{array}{l}\text { Employment } \\
(\%)\end{array}$ & $\begin{array}{l}\text { Unemployment } \\
(\%)\end{array}$ & $\begin{array}{l}\text { Inactivity } \\
(\%)\end{array}$ & $\begin{array}{l}\text { GVA per } \\
\text { head }(£)\end{array}$ & $\begin{array}{l}\text { Ave. earnings } \\
\text { PW }(£)\end{array}$ & $\begin{array}{l}\text { per 10,000 } \\
\text { people }\end{array}$ \\
\hline Pembrokeshire & 71.9 & 5.6 & 22.1 & 18,400 & 457.30 & 644 \\
Carmarthenshire & 73.1 & 3.1 & 21.5 & 15,900 & 495.70 & 560 \\
Swansea & 68.3 & 4.9 & 21.3 & 19,300 & 506.90 & 454 \\
Neath and Port Talbot & 72.7 & 4.0 & 22.1 & 16,200 & 586.70 & 363 \\
\hline
\end{tabular}

polycentric nature of the city region as the dominant patterns of travel largely map onto the LA footprint. The TTWAs therefore split into a series of commuting patterns that do not suggest the city of Swansea has a substantial pull upon its surrounding locales.

This reflects an economic reality of the city-region with areas possessing very different economies and, therefore, somewhat divergent economic interests. This variable picture at the local authority level is also reflected in the descriptive statistics for the city-region (see Table 1), which suggest further the lack of economic dominance for Swansea as metropolitan centre. This in part reflects an urban/rural split and paints a mixed picture for the city-region, whereby there is reduced employment in Swansea and less businesses per 10,000 people in Swansea and Neath and Port Talbot (NPT) (with higher populations) but there are higher incomes in the more urban local authorities, and Swansea achieves a higher gross value added (GVA) per head than its surrounding local authorities.

This is compounded by a relatively weak economic performance for the city-region as a whole, when compared to the rest of Wales and the UK. Using Welsh Government (2019) statistics, it has the lowest employment rate $(71.1 \%)$, the second highest unemployment rate $(4.4 \%)$, the highest inactivity rate $(21.7 \%)$, the lowest GVA per head $(£ 17,600)$ and the lowest gross disposable household income (GDHI) per head $(£ 15,600)$. As these figures are then broken down into LA areas (see Tables 1 to 3 ), a mixed picture of both convergence and divergence of metrics is apparent. Table 1 shows how Swansea has marginally weaker levels of employment with moderately better levels of GVA per head. This does perhaps point towards a weak agglomeration effect for the city of Swansea when compared to the wider city region but one that is marginal at best.

The lack of economic dominance is further highlighted when looking at the cityregion's business profile, in terms of firm size, employment and types of industry (see Tables 2 and 3). Here, Swansea does have a larger labour market, with more businesses and bigger employers but it is only a moderate difference when compared to rest of the city-region. In the context of these figure, the TTWA, the aforementioned urban/rural split and Swansea's relatively weak economic performance as a city, collectively, this highlights how the city of Swansea is a non-dominant economic centre of the city-region. This therefore raises questions about the applicability of the city-region approach for SBCR in terms of economic development. The underlying mechanism for growth, in a city-region as posited by the UK Government is by harnessing the positive externalities of agglomeration (a highly questionable premises in itself, see Haughton et al., 2014 and 2016), in a 
Table 2 Firm size and related employment number (Welsh Government, 2019).

\begin{tabular}{lccccr}
\hline & Micro (0-9) & Small (10-49) & Medium (50-249) & Large $(250+)$ & Total \\
\hline Enterprises by size band & & & & & \\
$\quad$ Pembrokeshire & 14,090 & 560 & 120 & 210 & 14,980 \\
$\quad$ Carmarthenshire & 14,505 & 600 & 160 & 290 & 15,555 \\
$\quad$ Swansea & 18,405 & 755 & 225 & 445 & 19,825 \\
$\quad$ Neath Port Talbot & 6890 & 365 & 130 & 210 & 7595 \\
Employment by size band & & & & & \\
$\quad$ Pembrokeshire & 23,500 & 9900 & 5600 & 9400 & 48,500 \\
$\quad$ Carmarthenshire & 25,200 & 10,600 & 7300 & 18,700 & 61,800 \\
Swansea & 28,700 & 13,800 & 10,200 & 41,200 & 93,900 \\
$\quad$ Neath Port Talbot & 11,700 & 6400 & 6900 & 16,500 & 41,400 \\
\hline
\end{tabular}

Table 3. Employment by industry (Welsh Government, 2019).

\begin{tabular}{|c|c|c|c|c|c|c|c|c|}
\hline & $\begin{array}{l}\text { Agriculture, } \\
\text { forestry and } \\
\text { fishing }\end{array}$ & Production & Construction & $\begin{array}{l}\text { Wholesale, } \\
\text { retail, } \\
\text { transport, } \\
\text { hotels and } \\
\text { food }\end{array}$ & $\begin{array}{l}\text { Information } \\
\text { and } \\
\text { communication }\end{array}$ & $\begin{array}{l}\text { Finance and } \\
\text { insurance } \\
\text { activities }\end{array}$ & $\begin{array}{l}\text { Real } \\
\text { estate } \\
\text { activities }\end{array}$ & $\begin{array}{l}\text { Professional, } \\
\text { scientific and } \\
\text { technical } \\
\text { activities }\end{array}$ \\
\hline Pembrokeshire & 4500 & 4300 & 5300 & 18,200 & 600 & 500 & 700 & 5400 \\
\hline Carmarthenshire & 5700 & 9900 & 5500 & 18,900 & 1300 & 700 & 1100 & 7600 \\
\hline Swansea & 200 & 7600 & 8000 & 30,700 & 2900 & 5300 & 1800 & 16,900 \\
\hline $\begin{array}{c}\text { Neath Port } \\
\text { Talbot }\end{array}$ & 200 & 9600 & 4200 & 11,600 & 500 & 400 & 900 & 4200 \\
\hline
\end{tabular}

more polycentric context like SBCR, this seems an unwieldy fit.

It is upon this mixed and varied economic picture that the city deal was negotiated between the four local authority areas, the UK Government and the Welsh Government (see Figure 1). This presented a complicated process for negotiation and much like the CCR City Deal (see Beel et al., 2018) was a product of tensions between local authorities and the Welsh State in the context of potential local government restructuring plans, alongside tension between the Welsh and UK Governments in terms of delivering the city-region concept (see Pemberton, 2016). The delivery of the city deal was proceeded by the Swansea Bay Transition board, which was led by the Sir Terry Matthews (a leading private-sector elite and Wales' first billionaire) and this initiated as a process of city-region building by the Welsh Government (Swansea Bay City Region, 2016). The initial plans were based on the ambitious concept of an Internet Coast to secure 5G digital capability for South Wales and bring about an upward shift in the productivity capability of Swansea's advanced manufacturing base through 'catapulted' technology. The SBCR City Deal document, signed in March 2017 (HM Government, 2017), though reflected the product of negotiations between the Local Authorities themselves over their immediate (rather than forward looking) priorities and the UK Government over what was permissible Treasury expenditure at that time. This complicated deal-making structure, alongside the economic geography of Swansea Bay, therefore, greatly reflects 
what was delivered and supports the claims made above by Scott that 'city-regions are always at the same time conditioned by idiosyncrasies related to local material, social, and cultural circumstances' (Scott and Storper, 2003: 574).

In summation, the SBCR City Deal secured $£ 1.3 \mathrm{bn}$ of funding for its 11 proposed projects, whereby $£ 637 \mathrm{~m}$ was projected to be leveraged finance from the private-sector and with the Welsh and UK governments having committed in principle to $£ 241 \mathrm{~m}$ of that total. The city deal further aims to deliver a 'collective focus' for the city-region. The signed version notes that:

The City Deal provides clarity of purpose, consistency of approach and absolute focus on collective action over the next two decades. We aim to tackle the structural challenges holding back our economy and reduce the gap between our performance and the rest of the UK in terms of wealth creation to the benefit of both. (Swansea Bay City Region, 2016: 2)

The deal was to be implemented over the next 15 years, aiming to boost the regional economy by $£ 1.8$ bn and generate almost 10,000 new, high-quality jobs. It was split into four main themes: Internet of Economic Acceleration; Internet of Life Science \& Wellbeing; Internet of Energy and Smart Manufacturing. These four themes were then further split into 11 different projects, of which, only three operate across the cityregion scale as a whole (see Figure 6).

The lack of operation across the cityregion as a whole highlights the lack of economic convergence, as well as the need, in political terms for each local authority, to see some aspect of the deal landed in their area for the purposes of political legitimacy. Despite this, the deal makes clear that it is about ensuring economic growth for the city-region and widening its economic footprint:

The Deal provides an opportunity to continue tackling the area's barriers to economic growth through: developing higher value sectors and higher value employment opportunities to match; increasing the number of businesses within these sectors to widen the economic base; and improving the region's GVA level against the UK average. As well as taking forward

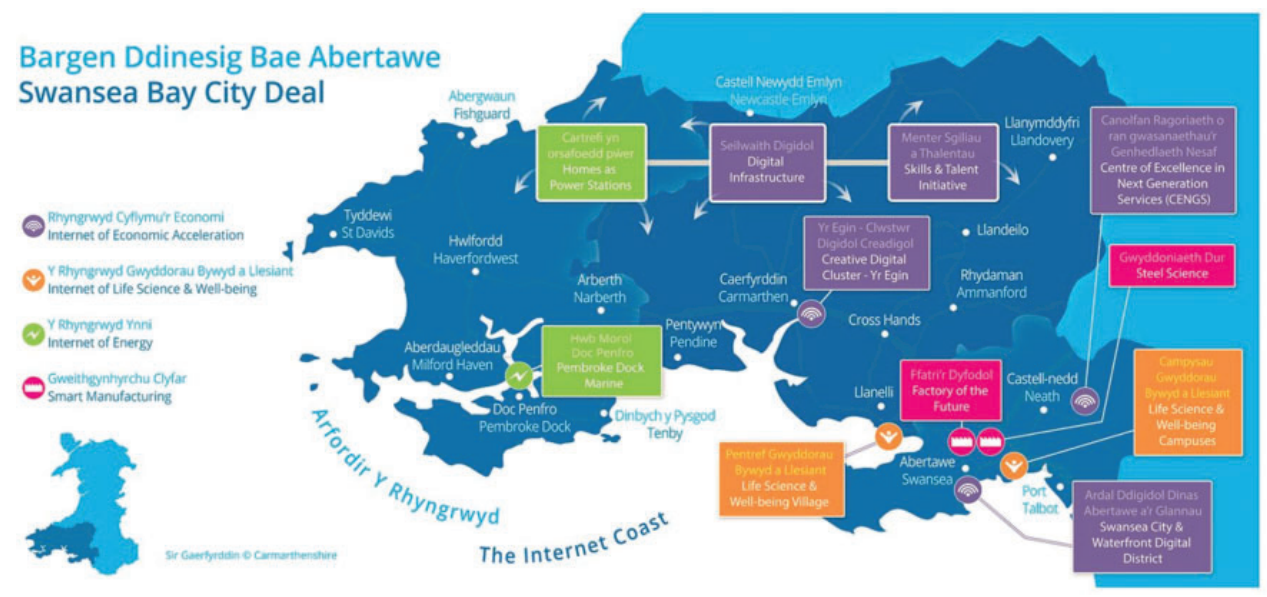

Figure 6. The Swansea Bay City Deal (2016). 
programmes to drive economic growth the City Deal commits local leaders and partners to implementing effective leadership across the City Region. (Swansea Bay City Region, 2016: 3)

The deal, therefore, attempts to improve a struggling city-region economy following specific markers of success such as GVA uplift. It attempts to do this via attracting, or creating in situ, high-end businesses primarily related to health, improving digital infrastructure and in the specific regeneration of parts of Swansea's urban core.

\section{Quite a city-regional stretch: Emerging critiques}

The above SBCR City Deal, despite the bombast and optimism of local elites involved in its implementation, papers over a number of structural and strategic weaknesses within the South Wales economy and its 'geo-constitution' (Wills, 2016). Not least pertaining to a breakdown in the governance of the city deal implementation itself due to gross misconduct, which resulted in several high-level suspensions from public office and later criminal investigations by the Regional Crime Unit for Southern Wales over the misuse of public money to support private business interests in the controversial Llanelli Wellness and Life Science Village project. ${ }^{1}$ These were ongoing during the period of our research and are outside the scope of this paper, but needless to say they do not support the argument that devolution through localist city-region building represents a role model of democracy, the basis for civil society awakening, or virtuous economic and social renewal more broadly. The scope of this paper is not the governance of the SBCR City Deal per se, but with the deeper concern with applying the cityregion framework and its limits.

\section{Conflicting aspirations}

As has been alluded to, the city-region has been negotiated between a set of conflicting aspirations, which are presented via each of the key institutional actors' concerns as to what they wish to see developed from the city-region building process. This is reflected in the views of the Welsh Assembly's Economy, Infrastructure and Skills Committee who suggest that:

It is clear that Deals and the investment that follows them have given the UK Government a role in economic development that (as a devolved area) would normally be the preserve of the Welsh Government. If this joint working is harmonious, then there is strong potential for it to benefit all parties. However, there is a history of fractiousness and finger-pointing between the two governments, particularly when it comes to economic development and infrastructure projects in areas where devolved responsibilities are not 100\% clear. (Economy, Infrastructure and Skills Committee, 2017: 18-19)

From this grounding for conducting and delivering city deal, a deal that keeps all groups happy was always going to be difficult and is always going to require significant compromise. This especially pertinent in terms of thinking through what sort of economic growth is wanted and who does it benefit. For example, there are differing legislative approaches to economic development from the UK and Welsh Governments, and for the UK Conservative Government there is an emphasis on 'city-first' agglomerative growth. This fits well with perhaps what local elites in Swansea would emphasise as important too, as it places emphasis on the city itself and the search for urban wealth creation. Whereas the Welsh Government (Labour), although not ideologically against agglomeration per se, supports an alternative 
ideological model of economic development, predicated more on achieving spatial justice (see Jones, 2019; Jones et al., 2020; Welsh Government, 2015a) via the Wellbeing of Future Generations Act (2015). This is reflected in the below quote:

I guess strategically where we were and in the four months of negotiations strategically we had to fulfil the ambitions of both governments and as you say you've got a Labour Government here, a Conservative Government in Westminster, so we had to have the capability really of knowing what both governments' agendas were and how to marry those two agendas and we're still doing it post-negotiation. We still have to marry two strategic ambitions together but I guess it helps that officials from Welsh Government and UK Government can come to an agreement themselves and have one path forwards. (Interview, Local Government Leader, 2018)

This implies the need to integrate the desires of both Governments in terms of what they consider to be appropriate economic growth, but it also positions the divergent rural and urban local authorities away from more longterm strategically planned approaches. As we suggested above, local political legitimacy becomes important. This is because for the city-region as a whole, partners are required to deliver a deal, which they derive some form of benefit from. This, in turn, localises policy away from city-region wide projects and concerns, which are unable to be integrated with local territorial concerns. This, in empirical terms, also points to the need to consider the dynamics of 'metrophilia', which we now turn to examine.

\section{Dealing with metrophilia}

You've got an opportunity here as a region, Swansea is known globally now because of the football, you've got to use that brand to reach out to the world to attract people to come here.' He said, I think that was accepted. And on top of that then, if you accept Swansea is 'As much as we would like to describe Carmarthenshire and Pembrokeshire and all the other great areas within the region, Swansea is your brand. That's why it's Swansea Bay.' the engine of the region, the major urban centre, the major economic centre of the region, then if you get the engine running well you are going to disperse that wealth out into the other parts of the region. (Interview, Local Authority Leader, 2018)

The logic of the above local authority leader, gets to the nub of the point 'Swansea is your brand' - not the 'South West Wales City Region' or any other name, but Swansea itself is front and centre. The emphasis is also made on the city being the major economic and urban centre, in short the metro-centre for making the city-region 'work'. The quote also highlights the belief in a trickledown effect from the development of Swansea itself but as has been noted, the weak economic ties of the city-region and the unevenness of agglomerative growth suggest that this will be a struggle to provide growth across the city-region. This argument is shared by actors in the region:

Now Pembrokeshire was not keen on the city-region approach I think because of our experience of city-regions. When we're sitting on the periphery of it the Region looks very different sitting in West Wales than it does sitting in Swansea. So, if you're sitting in Swansea the City Region Deal looks like a pretty good thing, but we're a long way from Swansea. (Interview, Civil Society Leader, 2018) 
The positioning here of Pembrokeshire as the most peripheral (and rural) to Swansea is key to the discussion and the comprehension of what a city-region economy will bring. For the SBCR, then, this is the 'construal' (Jessop, 2016a) within the city-region building narrative; that for underperforming and smaller metropolitan centres, any form of trickle-out to the rest of the city-region is highly unlikely to surface. Metrophilia is clearly not the answer here for ensuring city-region wide economic and social development. This is further compounded by genuine rural development question for the city-region and the arguments rehearsed in North Wales also apply to the SBCR (see Beel et al., 2019 as well as Ward, 2006; Harrison and Heley, 2015) with the rural parts of SBCR.

As we have noted above (Figure 1), a large proportion of the region can be defined as rural and this has minimal economic connection to Swansea itself. It also presents itself with a series of other and differing development needs. The quote below highlights this in terms of health:

Well we're very, very concerned about it. Whilst the City Deal will concentrate on health and life science as a major investment, rural health is not being taken care of ... It's also got the issue of attractiveness, we've got this shift from rural areas into urban areas which leaves a vacuum then in terms of skills and the linguistic skills in that rural area so health is a growing issue...That's where I believe an English city-region has got the advantage in that it is an urban area, good communication links, high volume of people, good learning resources distributed. We haven't got that; we've got this rural aspect, which is difficult. (Interview, Former SBCR Board Member, 2018)

Within the city deal, there are a variety of projects that look to develop aspects of the city-regions health economy, but the specific rural needs are not addressed. Added to that, the above participant highlights a growing issue for rural areas due to the emphasis on projects that are urban, this in turn, creates the reverse of agglomeration in rural areas, as people leave. Interestingly, the SBCR does not differentiate its policy interventions along rural and urban lines. Again, the overly metro-centric focus is not the answer to rural problems, as it also exacerbates them.

\section{Austerity and financialisation}

Further problems are aggravated by the ongoing impact of austerity and the question as to how the city-region will be sustainably financed. Austerity has landed differently in Wales to England, with the Welsh Government buffering some of the impact, but this has still impinged on Welsh Local Authorities severely. In the quote below, the continuing effects of austerity against the local authority is even cited as reason to not continue with the city-region process.

We were going into a time of. ..well we're in a period of austerity, we cannot afford extra expenditure on things that are not known. This was, to me, was opening the doors - could be a series of unknowns, so I was very, very, very cautious, yes...I go back to my point at the beginning; in these days of austerity we've not got the funds. We are being cut back, cut back, cut back for the last five, six years. And we shouldn't, councils should not be relied upon as a charity for business expansion. There are programmes that are grants, if your business plan stacks up, there are banks that will lend you money. What I'm saying is, I think, that the Assembly and the English Government could be...forming their own bank, if you like, just allowing businesses to borrow 
cheaper money. That's the only reason that these schemes want in on this because it's borrowing cheap money, they can't get it the same rates from the banks or the private sector so of course they want a part of it. (Interview, Local Authority Leader, 2018)

Here, the interviewee links the two projects, city-region building and austerity together, but also more fundamentally questions the role of what a local authority should be doing in relation to supporting business. This highlights the Janus-faced nature of city-region devolution in England. Against a backdrop of austerity, based on these insights, a similar devo-dynamic is in play. This is further reflected in an uneasiness surrounding the financing of city deal too and the risk each local authority faces in supporting it (in the wake of austerity). Below, the discussion as to whether the city deal is based on 'capital or revenue' is illuminating, particularly as to how stretched local authorities are and the actual value placed on the city deal. According to one perspective:

And then there's the issue around what is the nature of the funding in the City Deal, if you read it, it says two different things; on one page it says that it's "funding", so that could be capital or revenue, over the page it says it's capital. Now I need revenue for one or two of the projects so I'm asking them to clarify, essentially. They started off saying it's all capital and I said, "oh dear". And now they are starting to back-track a bit, so it's all part of the negotiation. We've got a revenue requirement of thirty-four million quid, on two main projects, one of which is here and the other one is the regional skills programme and a few bits and pieces elsewhere, but basically there's a deliverability issue around the projects if we can't get the clarity. (Interview, Local Authority Official, 2018)
For the local authority official, the city deal being financed via capital funding is untenable, due to the upfront cost of project delivery. The vagueness in the city deal documents does not help and in turn, with stretched resources, has meant the need to negotiate further before the deal can be implemented, and this is a stark reality of negotiating the city-region building process. Here, austerity and the process of negotiating the deal between multiple actors and the requirement of the state to support businesses with funding, raises a series of difficult questions for the on-going implementation of the city deal.

\section{Trickle-out ...}

The possibility of around $£ 1.3$ billion in funding being available for investment does offer a number of opportunities to deliver the projects in the SBCR City Deal and this level of funding is, of course, attractive to private investment. Therefore, as the local authority leader below suggests the scale, of this interest is genuinely global in its offering:

I think the investment from both governments is just giving us the profile that private sector want to invest and it's the catalyst. Because both governments want to invest in the region. We're already seeing global investors wanting to talk to us... there are companies talking to us now that we've never seen in Carmarthenshire but they're here now because of the City Deal and what that offers and that's great to see. (Interview, Local Government Leader, 2018)

Questions remain as to whether the projects, as outlined in the city deal, will have the level of economic impact city-region actors suggest, but with such 'global' external interest, another fundamental question opens up. How much of the proposed $£ 1.3$ 
billion investment will remain in the cityregion, to be appreciated by the regional civil society of the Swansea Bay? For some, this is another failing of city-region building process itself, whereby not enough attention has been concentrated on cityregional welfare-capture, to influence the politics of distribution thereafter. According to one source:

I had probably three or four objectives the biggest one being fair procurement. Probably the second one a voice for construction and hopefully probably lining up with yours localism as well. I wanted to get the local point across that construction is the first rung on the ladder when it comes to investment and so on... Obviously a lot of people didn't agree with my views. I did bang on all the time about procurement and it needed to start with Smart Fair Procurement but I've written there that was totally lost to be honest with you. I couldn't get it written into the City Region Deal and I think that's the most important. The enabler for the whole of the City Region Deal is the construction so whether or not the project is on infrastructure or it's on life science, wellness centre as one is or it's on the city centre regeneration it starts with construction. (Interview, Former SBCR Board Member, 2018)

The above quote highlights how as a Board Member participant within the process of developing the city-region, there is an inability to guarantee that the funding coming to Swansea Bay will remain with its economy. Again, this highlights a further critique to the city-region policy construct as it is currently premised; this spatiotemporal fix cannot find ways to ensure that, even if it creates an agglomerative effect from investment, investment may not necessarily remain within the city- region crucible. This instead represents a form of trickle-out, whereby infrastructure, new buildings and so on maybe built, but with an increasingly fragmented or even 'dismembered' (Toynbee and Walker, 2017) local state, little of its economic footprint will ultimately remain in the cityregion.

\section{Conclusions}

You could call it the hegemony of a laissez faire - the neo-liberal hegemony. To use that phraseology: it's the dominant philosophy, isn't it? And I don't think that has been challenged. You've got Jeremy Corbyn and John MacDonald coming in but even there I suspect that's more about macro-economic policy and it really strikes me again that, in my experience of politicians, they know very little about this area so they tend to assume what (hacks it) in terms of economic development is big buildings and roads, something tangible. I come back to my point, in economic development terms in Wales there's too much development and not enough economics. (Interview, Health Board Chair, 2018)

This paper has sought to expose the immense difficulties of instituting a cityregional model of economic and social development for the SBCR, which is a collection of polycentric medium-sized urban entities, historically battling for recognition as nodes in the increasing globalisation of capital networks. We have highlighted the pre-existing economic tensions in this locality of South Wales, namely an agglomerative economy riddled with weak links and connections within and between the towns and cities. The city deal does nothing short of replicating and extenuating these economic and social problems. Overtime, the local authority and city-centric dominated 
strategy has led to the lack of a city-region wide spatial strategy, with emphasis being placed on too many geographically discreet projects, which are used to both secure political legitimacy and also partially plug the gaps left behind by the decade of austerity. In the words of one influential academic commentator:

Dylan Jones-Evans ... reportedly said that the deal had gone away from "investing in infrastructure and people" towards "building more buildings". He argued that the strategy taken had "been discredited by economic development organisations around the world". Professor Jones-Evans criticised the deal for moving away from funding and skills for business by no longer having an infrastructure or investment fund and claiming that less than $1 \%$ of the budget specifically earmarked for skills. In addition, he argued that the emphasis on new digital technologies, which was at the heart of the proposition document, had been cut back to a single funded project. Most worrying, he argued, was the absence of any funding to support the proposed installation of a new transatlantic cable from
North America into Oxwich Bay. This project, Professor Jones-Evans argued "has the potential to totally transform the economic fortunes of the whole of South Wales". (quoted in House of Commons Welsh Affairs Committee, 2019: 19)

Within this context of political capture by certain local state elites, Figure 7 captures the current (August 2020) status of the SBCR City Deal projects. Essentially, three projects in the original vision (Centre of Excellence in Next Generation Services, Factory of the Future and Steel Science) have been replaced by the Supporting Innovation \& Low Carbon Growth project in the Neath Port Talbot area. ${ }^{2}$ Economic development officers within the supporting local authorities are at pains to point out that steel science and smart manufacturing elements are now contained within the Supporting Innovation \& Low Carbon Growth project. Critics though point to this being more about protecting the initially allocated funding parameters and safeguarding the interests of steel production in Port Talbot than providing the basis for increased economic productivity and shared prosperity across the SBCR.

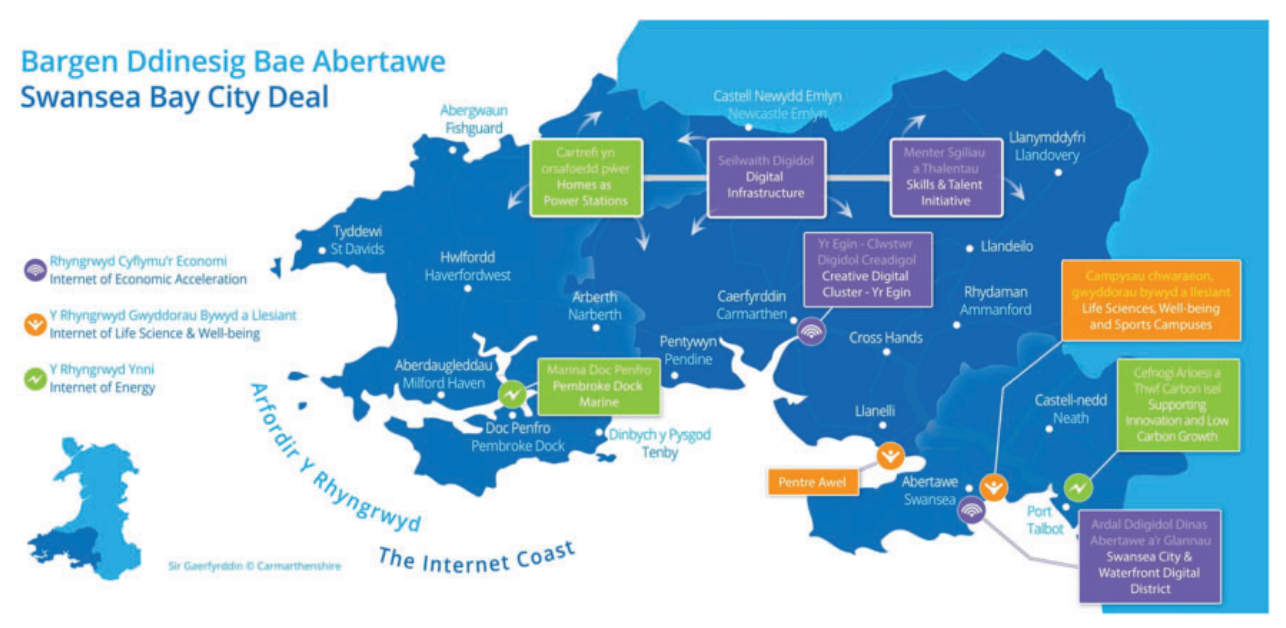

Figure 7. The Swansea Bay City Deal (2020). 
As the city-region building 'round of institutional investment' (Peck and Tickell, 1995), then, has been rolled-out over this existing complex geography, we would argue that in years to come, this (curtailed) model of economic development will indeed exacerbate combined and uneven development, and furthermore it will not lead to the empowerment of civil society actors to be able to 'formulate an agenda, act and make change' (Wills, 2016: 13). This raises questions with regard to what an appropriate 'growth' strategy would be for places like the Swansea Bay. As a final note, these issues have been further exacerbated by the COVID-19 crisis, whereby, the very model of urban agglomeration is thrown into question. In this context and with potential changes in terms of where and how we work, is a more decentralised, polycentric region actually more of a benefit for future theorisations of economic growth?

\section{Declaration of conflicting interests}

The author(s) declared no potential conflicts of interest with respect to the research, authorship, and/or publication of this article.

\section{Funding}

The author(s) disclosed receipt of the following financial support for the research, authorship, and/or publication of this article: The authors acknowledge the support of the Economic and Social Research Council (ESRC) [grant number ES/L009099/1, and ES/S012435/1 Wales Institute of Social \& Economic Research, Data \& Methods (WISERD) Civil Society].

\section{ORCID iD}

David Beel (D) https://orcid.org/0000-0002-1146$229 \mathrm{X}$

\section{Notes}

1. See https://www.walesonline.co.uk/news/ wales-news/police-reveal-project-centre-swan sea-16679624
2. https://www.swanseabaycitydeal.wales/news/ regional-green-light-for-587-million-neathport-talbot-programme/

\section{References}

Beel D, Jones M and Jones IR (2018) Elite citydeals for economic growth? Problematizing the complexities of devolution, city-region building, and the (re) positioning of civil society. Space and Polity 22(3): 307-327.

Beel D, Jones M and Plows A (2019) Urban growth strategies in rural regions: Building The North Wales Growth Deal. Regional Studies 1-13.

Blackaby D, Drinkwater S, Murphy P, et al. (2018) The Welsh economy and the labour market. Welsh Economic Review 26: 1-12.

Clarke N and Cochrane A (2013) Geographies and politics of localism: The localism of the United Kingdom's coalition government. Political Geography 34: 10-23.

Conservative Party (2015) The Conservative Party Manifesto 2015.

Deas I (2013) The search for territorial fixes in subnational governance: City-regions and the disputed emergence of post-political consensus in Manchester, England. Urban Studies 51(11): 2285-2314.

Economy, Infrastructure and Skills Committee (2017) City Deals and the Regional Economies of Wales. Cardiff: Economy, Infrastructure and Skills Committee.

Etherington D and Jones M (2016) The cityregion chimera: The political economy of metagovernance failure in Britain. Cambridge Journal of Regions, Economy and Society 9(2): 371-389.

Etherington D and Jones M (2018) Re-stating the post-political: Depoliticization, social inequalities, and city-region growth. Environment and Planning A: Economy and Space 50(1): 51-72.

Gooberman L (2017) From Depression to Devolution: Economy and Government in Wales, 1934-2006. The University of Wales Press: Cardiff.

Harrison J (2014) Rethinking city-regionalism as the production of new non-state spatial strategies: The case of peel holdings Atlantic 
gateway strategy. Urban Studies 51(11): 2315-2335.

Harrison J and Heley J (2015) Governing beyond the metropolis: Placing the rural in city-region development. Urban Studies 52(6): 1113-1133.

Haughton G, Deas I and Hincks S (2014) Making an impact: When agglomeration boosterism meets antiplanning rhetoric. Environment and Planning A: Economy and Space 46(2): 265-270.

Haughton G, Deas I, Hincks S, et al. (2016) Mythic Manchester: Devo Manc, the Northern Powerhouse and rebalancing the English economy. Cambridge Journal of Regions, Economy and Society 9(2), 355-370.

HM Government (2017) Swansea Bay City Region City Deal. UK: HM Government.

Jonas AEG and Moisio S (2016) City regionalism as geopolitical processes: A new framework for analysis. Progress in Human Geography 42(3): 350-370.

Jones R (2019) Governing the future and the search for spatial justice: Wales' Well-being of Future Generations Act. Fennia - International Journal of Geography 197(1): 8-24.

Jones R, Goodwin-Hawkins B and Woods M (2020) From territorial cohesion to regional spatial justice: The Well-Being of Future Generations Act in Wales. International Journal of Urban and Regional Research 44(5): 894-912.

Lee N (2019) Inclusive growth in cities: A sympathetic critique. Regional Studies 53(3): 424-434.

Macleod, G and Jones, M. (2007). Territorial, Scalar, Networked, Connected: In What Sense a 'Regional World'? Regional Studies 41(9): 1177-1191.

Nathan M and Overman H (2013) Agglomeration, clusters, and industrial policy. Oxford Review of Economic Policy 29(2): 383-404.

O'Brien P and Pike A (2015) City deals, decentralisation and the governance of local infrastructure funding and financing in the UK. National Institute Economic Review (233): 14-26.

O'Brien P and Pike A (2018) 'Deal or no deal?' Governing urban infrastructure funding and financing in the UK City Deals 56(7): 1448 1476.

Overman H and Venables AJ (2007) Economic Linkages Across Space. London: Centre for Economic Performance.

Peck J and Theodore N (2015) Fast Policy: experimental Statecraft at the Thresholds of Neoliberalism. Minnneapolis: University of Minnesota.

Peck, J and Tickell, A. (2017). Neoliberalizing space. Antipode 34(3): 475-499.

Pemberton S (2016) Statecraft, scalecraft and local government reorganisation in Wales. Environment and Planning C: Government and Policy 34(7): 1306-1323.

Scott AJ and Storper M (2003) Regions, globalization, development. Regional Studies 37(67): $549-578$.

Storper M (2013) Keys to the city: How economics, institutions, social interactions, and politics shape development. Princeton University Press, Princeton.

Swansea Bay City Region (2016) Swansea Bay City Region: A City Deal 2016-2035. Swansea: Swansea Bay City Region.

Swansea Council (2020) Swansea Economic Profile. Swansea: Swansea Council.

Toynbee, P and Walker, D. (2017) Dismembered: How the Conservative Attack on the State Harms Us All. Guardian Faber Publishing: London.

Waite D (2015) City profile: Cardiff and the shift to city-regionalism. Cities 48: 21-30.

Waite D, Maclennan D and O'Sullivan T (2013) Emerging city policies: Devolution, deals and disorder. Local Economy: The Journal of the Local Economy Policy Unit 28(7-8): 770-785.

Waite D and Morgan K (2018) City Deals in the polycentric state: The spaces and politics of Metrophilia in the UK. European Urban and Regional Studies.

Ward N (2006) Rural development and the economies of rural areas. In: Midgley $\mathbf{J}$ (ed.) A New Rural Agenda. London: IPPR, pp. 46-67.

Welsh Government (2008) A Statistical Focus on Rural Wales. Cardiff: Welsh Government.

Welsh Government (2015) Well-Being of Future Generations (Wales) Act 2015. Cardiff: Welsh Government.

Welsh Government (2019) Regional Economic and Labour Market Profiles, October 2019. Cardiff: Welsh Government. 